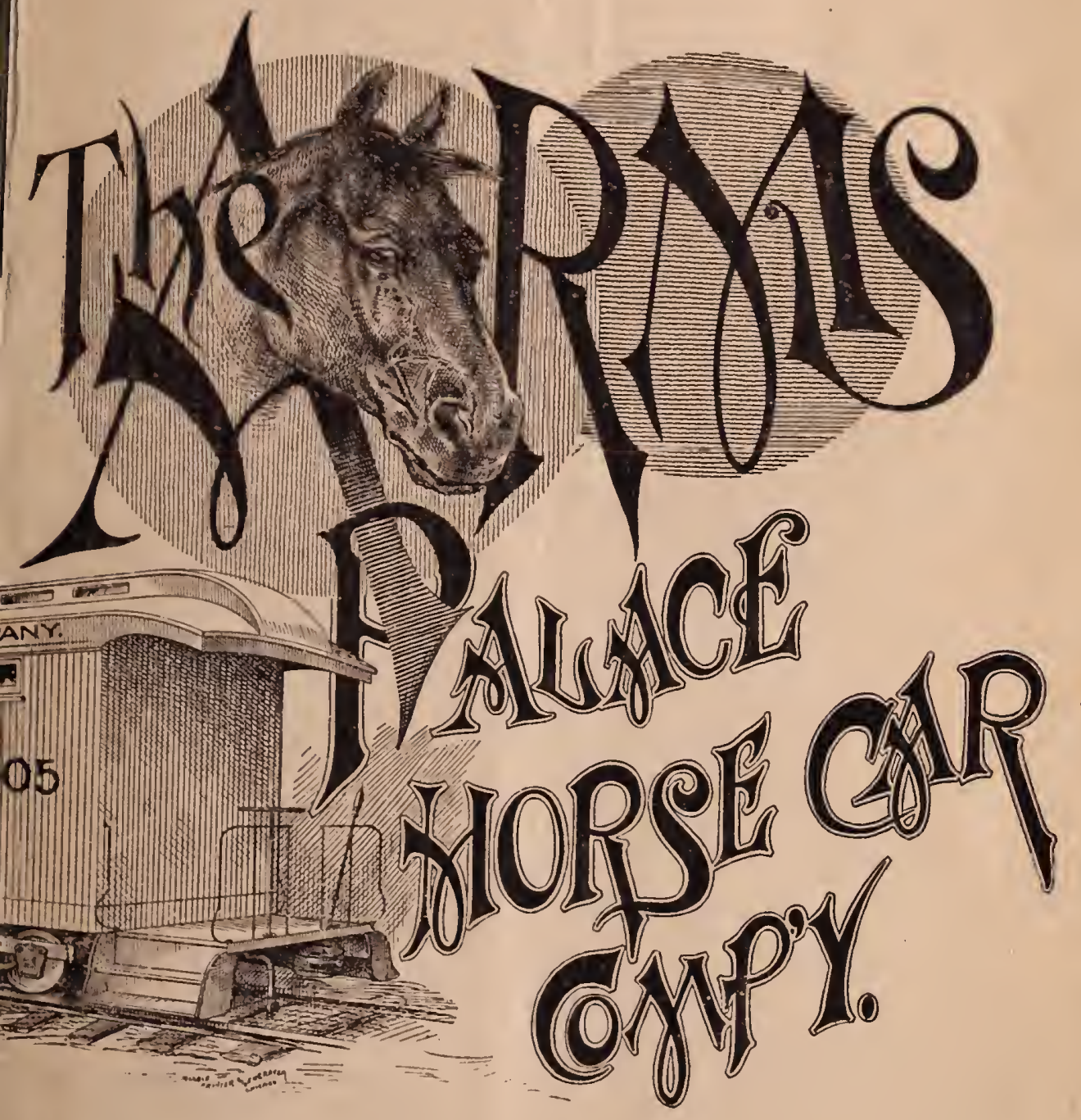




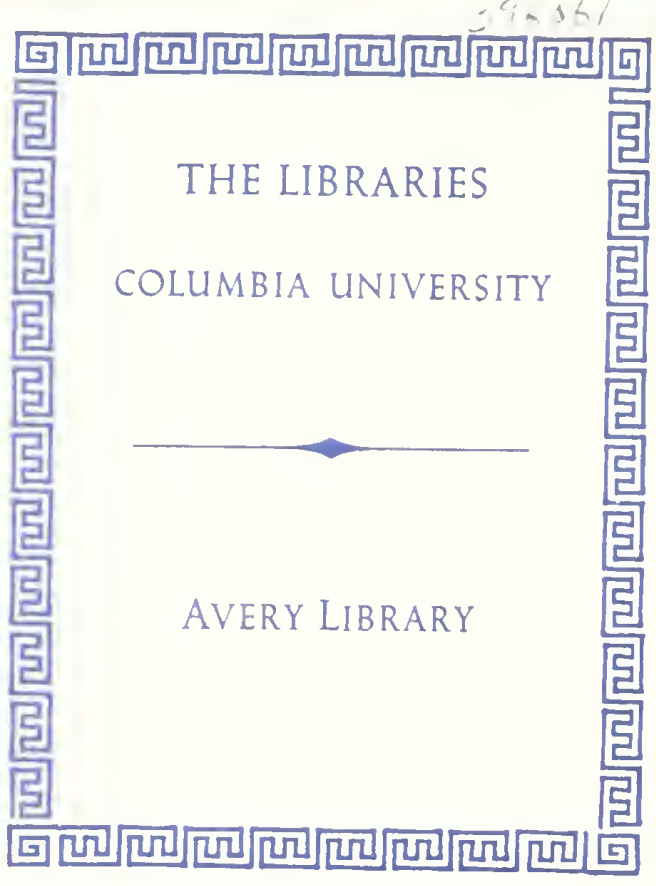




\section{THE ARMS}

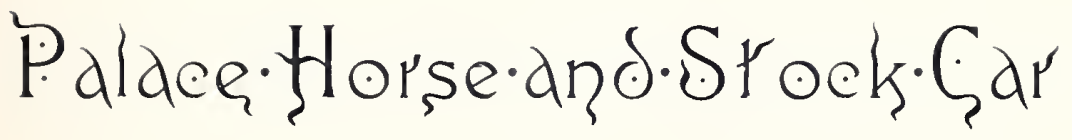

\section{Company.}

$$
\sigma^{2} \odot \approx
$$

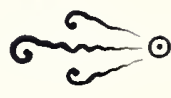

General Ofrices...............

$$
315-317-319 \text { "THE Rं̈OKERY." }
$$

$\bowtie$ CORNER LA SALLE $\propto$ ADAMS STREETS. $\infty$

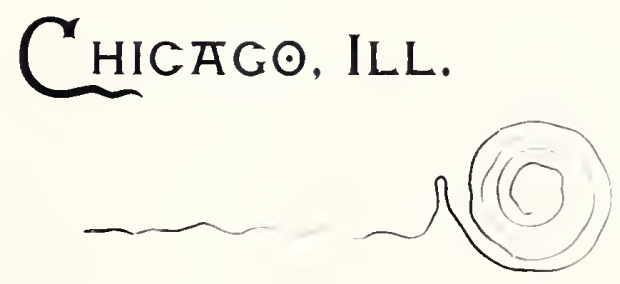

INCORPORATED UNDER LAWS OF OHIO

IN 1886. 
CHARLE L MAK:LE,

ART ENGRAVING AND PRINTING MOLISE, 170 MADISON STREET,

CHICACO.

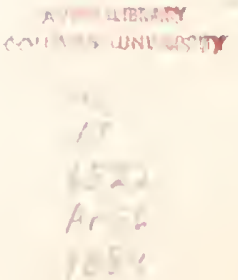




\section{○FFICERS}

\section{$\therefore(5) \cdot(\theta)=5$}

President ano general Manager。

Harrison Arms.

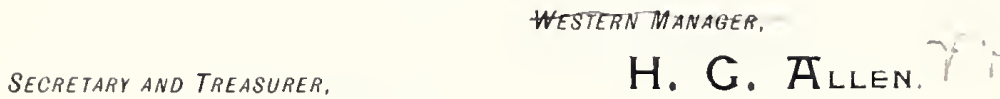

W. A. Y YGer.

...AGENTS...

G. W. GARRETSON,

GENERAL SOUTHERN AGENT.

$614 W$ JEFFERSON ST, LOUISVILLE, $K Y$.
H. A. BOYD,

GENERAL SOUTHWESTERN AGENT,

$1518 \mathrm{~N}$. BROAOWAY, ST. LOUIS
WM. STODDART,

598 GREENWICH ST.. NEW YORK,

W. H. FORCE,

CHEYenne, Wro. TER.

C. J. MURRAY, FORT COLLINS, COL.
J S. GILBREATH,

130 CHRISTIAN AVE., INDIANAPOLIS

GEO.W. CROUCH,

STOCK YARDS, KANSAS CITY

GEO. L. GOULDING \& CO.,

DENVER, COL

\section{G. H. HoOVER, east BufFalo, N. $Y$. \\ SHOIP AT COLLINIVOCD, OHIO.}

H. D. BARTLETT. - SUPERINTENDENT 


\section{Digitized by the Internet Archive in 2017 with funding from Columbia University Libraries}




\section{Announcement. 200}

@

UR EXPERIENCE in the shipping of Horses since the organization of this Company, the success which has attended all shipments in our cars, and the assurance we have from the many shippers and breeders who have extensively used the same, warrants us in the belief that we have, in every respect.

a practical and complete Car for the convenient, safe, humane and economical transportation of all grades and classes of Horses, and makes us free in recommending onr cars to all shippers for the following inclisputable reasons :

First. Our cars are well and sutstantially built, this being one of the principal points of consideration with this Company in the letting of contracts for construction, thereby rendering injury to animals next to an impossibility, on account of frail construction, weak partitions or insufficient snpport, and assuring to horses and owners almost the same sense of safety that would be experienced were they in a finely appointed stable.

SEcons. It is a well established fact. denoted by experiments and observation, and conceded by scientists, that the proper way to 
place a horse, whereby the fatigue of the journey will be reduced to the minimum, is spuarely crosswise of the car, and we have in the construction of our car, attained this one great point, and are enabled to offer to our patrons a car that will land horses at destination after a run of ten to twelve days, in as gool condition as when loaled, and making the delay and expense of "fitting" horses for market after reaching clestination, a thing of the past.

THIRD. Owing to the above facts mentioned in construction, and the perfect manner of rentilation in our car, the manner of supplying light and air, together with the perfectly natural ease of the horse, while car is in motion, prevents the average horse, and especially the nervously disposed horse, from fretting himself into it dripping perspiration. We overcome at once the great rlanger of contracting disease from improper drafts and poor rentilation, and at the same time overcome the stifling closeness that is experiencerl in the tight car, and also as before mentioned, the equal peril of the slat car.

Fourth, liy the readiness with which all classes of horses accustom themselves to our car, and the perfoct ease with which they wercome the longest journey, it becomes an injustice to unload them for feeding and rest, thereby relieving shippers from this great mnoyance and expense, which fact, taken into consicteration, reluces our service charge to the minimum, and lays bare the argunent that "l'alace cars cost too much," and not mentioning the fact, dear 


\section{$7-$}

reater, that horses shipped in any other manner require days of "fitting". which, of course means large feed bills and great expense before they can be mate presentable for sale.

IIth the above strong argments, which we llefy any person to gainsay. it grives us infinite pleasure to present to your kind consideration the ARMS PALACE HORSE AND STOCK CAR, which nOw prerents the best four gear old recorsl, being no longer an experiment, after four years of labor, of which the shipper has derived no imall share of the benelits. We invite your attention to the following chetailed description of our car.

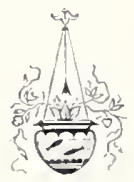




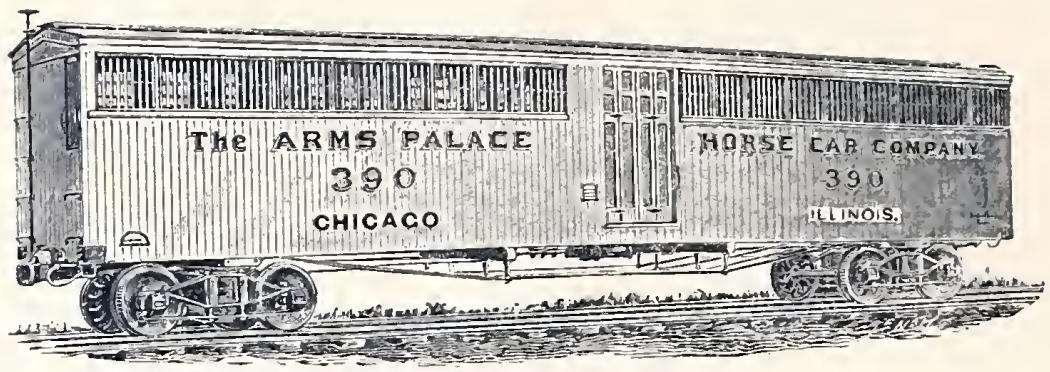

The above cut is probably familiar to all shippers of horses, showing the exterior of our regular line car. In appearance these cars are very attractive, being forty-six feet in length and painted a rich yellow. The largest portion of this equipment is supplied with Westinghouse Freight Air Brakes, thereby assuring to shippers the best and fastest runs.

We have made it a point in construction to provide our car with the best trucks and most perfectly adjusted elliptic springs obtainable, whereby a light or a heavy load ricle equally as easy, which is a point to be taken into consideration by all shippers, as being a great advantage over the ordinarily equipped cars.

Our cars all have eighteen stalls, which are twenty-nine and thirty-one inches in width. 
The following cut show horses as the stand loaded in rar.

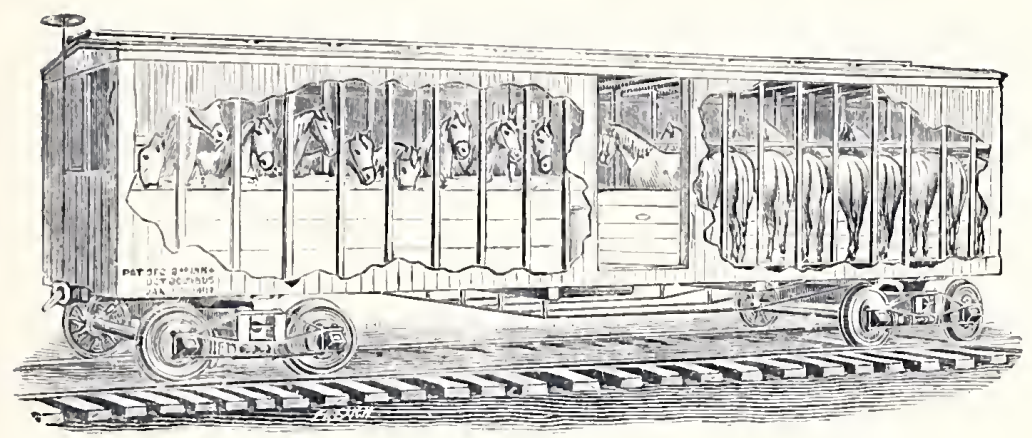

\section{PROVISION FOR FEED AND WATER.}

Cirs are provided with ample facilities for carrying feed and water, there being a water tank extending under manger, which is accessible from center of car, and having a capacity of three hundred sallons; also a bin extending under other manger hokling thirty bushels of grain. There is also a space in center of car six by nine feet, which is intended for attendant and enough baled hay for entire shipment.

\section{VENTILATION.}

Our perfect system of ventilation makes cars equally as desirable for shipment in warm as in cold weather. Ventilators are three feet in width, extending the entire length of car, and are made of galvanized iron slats, which can be opened or closed by a lever worked from the center of the car, the ventilators being covered on the outside by 
ralsanized wire cloth, which is a guard against flying cinders from the locomotive. We have also provided in front of the horses on the inside of car, heavy galvanized iron shutters. affording additional protection in extreme weather.

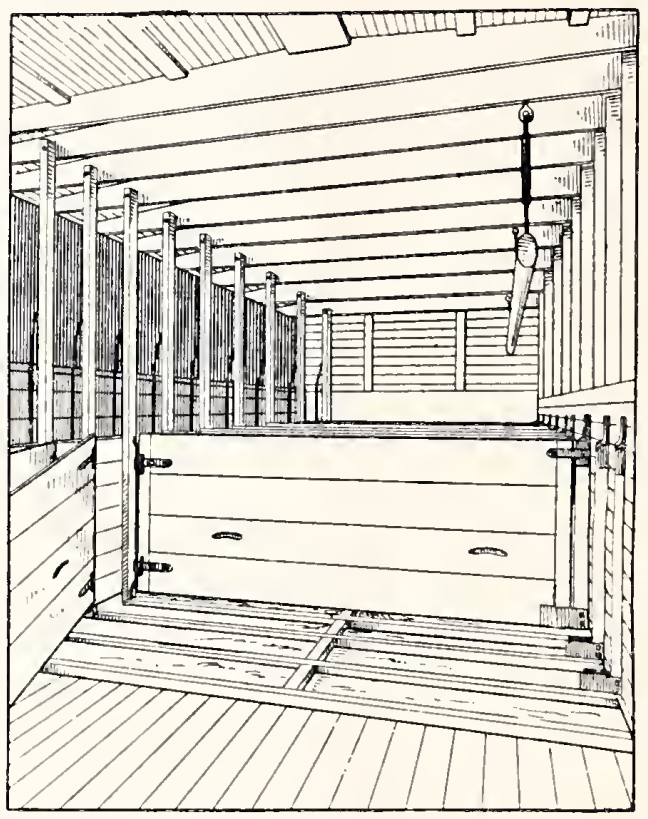

\section{GENERAL INTERIOR ARRANGEMENT.}

The abowe cut shows general interior of one end of car, with two partitions swung. There are nine partitions in each end of car. all of which swing arome to the manger, making loading a matter of great ealse. it only being necessary to lead the horse in. swing the 
partition around in place and latch it, which is accompanied by at little labor as leading a horse into a stable, and thereby wercoming the great difficulty experienced in some cars that require horses to be backerl into position. Stalls are well parted both in front and behind horses, making it impossible for horses to bruise their kncen or louckis.

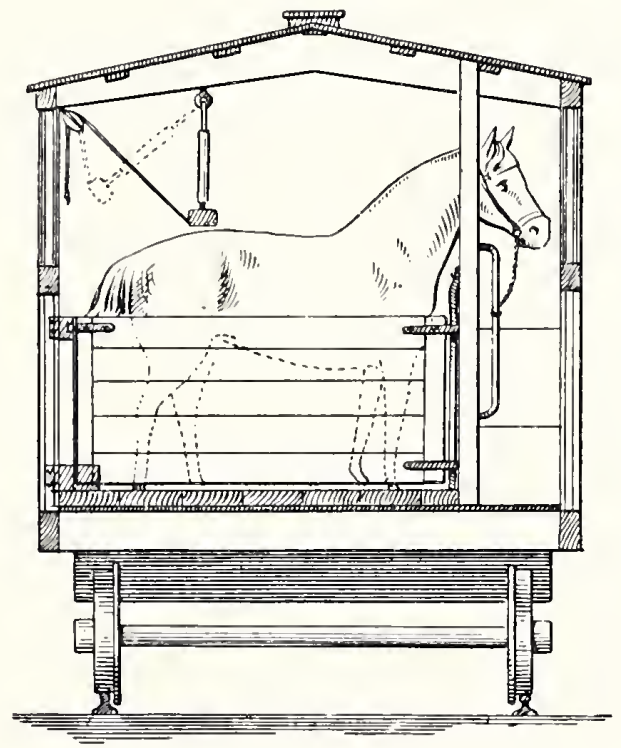

\section{THE HORSE INDIVIDUALLY.}

In accurate idea of the position of horse standing in stall and showing our manner of hitching, which is by a chain on each sicle of horse. which is supplied with a snap, and slides on an iron rod 
twenty-four inches long. giving a horse perfect freedom of his hear. but preventing him from biting his neighbor.

There is also shown in cut, a beam extending the length of car. which is dropped down and readily adjusted to hang a few inches above and directly over horses rumps. making it impossible for horse to raise up and kick over partition.

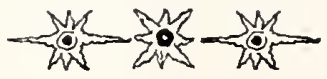

These cars are in general use throughout the United States, Canada and Mexico, and can be obtained by shippers at any point or at any time, by applying to local Railroad Station Agent, or upon application to our general offices, or any or our agents.

Rates will be cheerfully quoted for single shipments or for cars by the month, and we are always glad to correspond with shippers and give them any information required. 


\section{OUR SPECIAL CAR.}

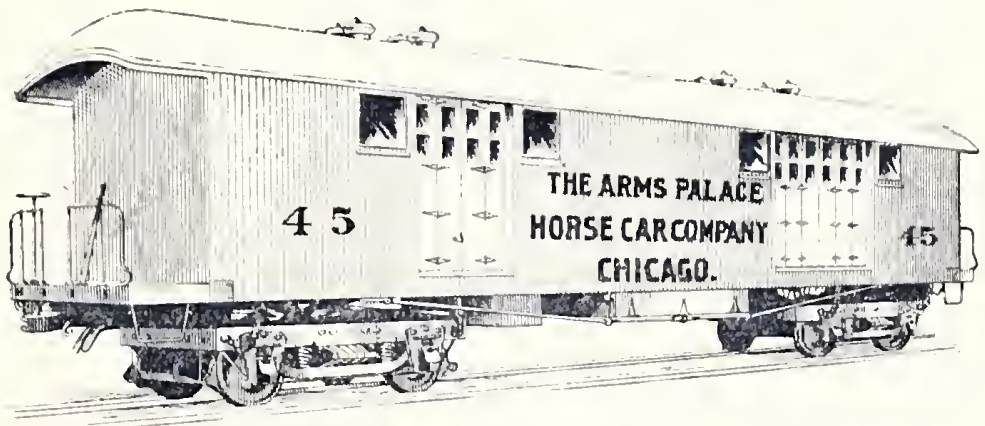

We have just completed and placed in operation a number o! the above cars, which are built expressly for the shipping of horses in passenger service or by express, and are especially arlapterl to the campaigning of racing stables, or trans-continental shipments, where shipping by freight becomes impossible or impracticable. They are also models of convenience for the TRANSPORTING OF FAMILY STABLES TO AND FROM SUMMER RESORTS.

As will be seen by the above cut, these cars are built in design similar to the ordinary passenger coach. They are supplied with every appliance necessary for passenger service over any railway. having the best improved passenger trucks, loth the Miller and Janney Coupler and the Westinghouse Complete Air System. including the Air Whistle signal. It is, therefore, with pride and pleasure that we offer to our friends this car. as being the most per- 
fectly appointed and complete car ever put before the public for the transportation of racing and family stables.

\section{ARRANGEMENT OF THE CAR.}

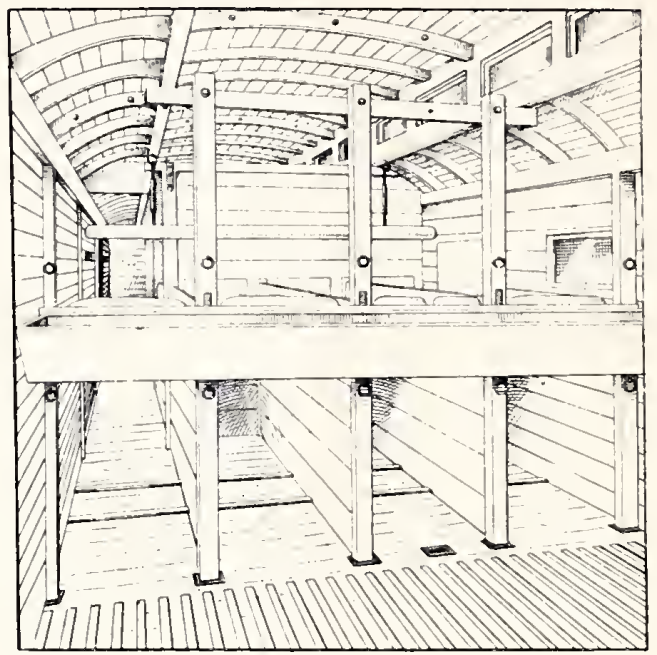

The cars are divided into four sections of four stalls each, the above cut showing one section, making accommodations for sixteen horses. All stall partitions are strong and substantially built, and are so arranged that a section of four stalls can with the greatest ease be changed to make three single stalls, one double and two single, two domble stalls, or one box stall, or the stalls can be removed entirely and the space utilized for luggage. We also have for luggage and stable accoutrements, large boxes under the car, which also 
give ample accommolation for feed or for the storage of stall partitions when not in use. ('ars are also supplied with two water tanki, which are easy of access and a great comenience.

These cars are forty-four feet in length: the stalls are ample in size. both in length and width, and the spaces at the doors between the sections are unusually large, being six feet in one end of car and ten feet in other, and the loors in one end are ten feet wide, through which a carriage can be run without taking off the wheels.

Stalls are generously supplied with padding. which is of superior material, and very easy for horses. There are also large feed boxes which can be very readily arranged, and when not in use are stored uncler car.

There is also, for further convenience, a passage learling from one end of car to other, which being just the wilth of stall, a horse can be led from one end of the car to the other, but the door when closed, makes a solid wall.

In the ventilating of these cars we think we have reached the acme of perfection, and the ventilating facilities are such that, while there is always an abundant supply of fresh. pure air, the danger of draughts is overcome.

Any further information regarding these cars or our regular line cars will gladly be furnished from the (ieneral Office, and we solicit correspondence.

Aclelress all communications to the Secretary. 


\section{TESTIMTPNIALS}

\section{FROM LARGE SHIPPERS, IMPORTERS AND BREEDERS.}

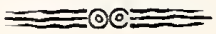

lioston, Feb. 25th, ISS9.

1I. A. Yager, Secy Arms Palace Horse Car Co., Chicago, IIt.

Dear Sir:- I wish to send you herewith my unsolicited testimony of the desirability of the Arms Palace Ilorse Car in the shipment and transportation of horses for long or short distances. I have used them for several years, and my experience with them has given me grcat satisfaction. During the past year I shipped over six thou sand horses from the several Western States, fully three-quarters of which were shipped in yourcars, and all of them arrived in good condition, without injury to hocks, hips, knees or eyes, that are incidental to the shipping of horses in common cars, and allowing s'ock to arrive in a healthy sta e and excelient condition for mar ket. Especially have I noticed this during rough or stormy weather. My shippers all spcak of your car in the highest terms, stating that the opportunitics for the care of stock while in transit are the best. I should very much dislike to be obliged to use common cars after having had the satisfactory experience I have with the Arms Palace Horse Cars. Very truly yours, J. C. RICHARDSON.

Combination Snle Stables, 273 Friend St., Boston, Mass.

Betridere, Ill., Jan. 24, IS89.

11. A. Yrrger, Sec'y Arms Palace Ilorse Car Co., Chicago, Ill.

Dear Sir:-We wish to make arrangements to use your cars another year. We have been handling horses for thirty years, shipped to Albany, N. Y., Pittsfie.d, Mass., St.Paul, Minn., Denver, Col., and other points occasionally. Have used your cars since they came in use with good results. Ifave used others when we could not set yours, and did not like the change. The Arms Palacc Horse Car fills the bill. Do uot think it necessary to try to better them. With them you can keep getting there and take carc of the stock about as well as you can in the barn. There are several advantages in using them that more than make up the extra chirge. Please give us lates to the above points, also from here to (hicago, we sometimes ship there, and though it is but a few miles, it is better to use your cars, as the first run is the hardest in stock, and in open cars they jam about, get heated, and are liable to take cold, and many are lost that way.

Respectfully yours,

TURNER \& HANNAII. 


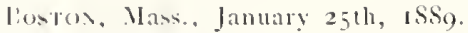

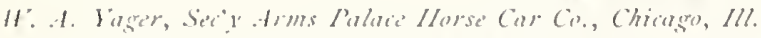

lear Sir:-We have used the Irm- Palace (ar extensively iu wur business eve sinec the same has been known to the public. The fact of so doing is better evidence of our opinion of it than s.nything we can write. Accept our thanks for prompt attention always given orders for cars, and wishing you continued prosperity, we remaiu,

$$
\text { Very tuly, CHARLES II. \& ELGAR SNOW. }
$$

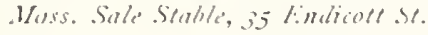

NeWl lokk, Jan. 23 d, 1889.

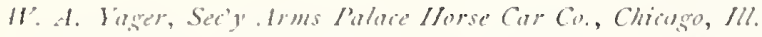

Jear Sir:-I take pleasure in recommending the Irms Palace IIorse Cars, and would recommend them highly to horsenen in particula and the public in general, requiring cars for transportation of valuable horses any distance, for safety, conven. ience and time saved in reaching destination. llorses shipped in Arms Cars do not show any signs of wear or fattigue. When unloarled they come out fresh and in lealthy condition. Having had occasion to use the Arms lalace Horse Cars, I linow from experience the benefits dcrived from them.

$$
\text { Vours very respectfully, I. II. DAHIMAN. }
$$

Wherty, Iowil, Jany, 2Ist, I $8 S_{9}$.

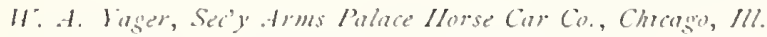

Derr Sir:-I consider the Arm; Palace Cars the most practical horse cars in use. having userl them nearly every week for the past six years, shipping as high as zoo head per week to C. H. Hansone \& Co, Lowell. Mass, and have never lost once horse on the roal. My horses arrive ready for market and work, and we used tw think we couldn't offer a horse for sale until rested screral days, and we think we save money by using them.

Respectully yours, E. KNOTT.

Wokcestrer, Mans, Jamuaty $22 \mathrm{~d}, \mathbf{1} 889$.

IV. A. Iasere, Sec'y Arms Palace Horse Cur Co., Chicago. Mll.

Dear Sir:-I run the first Arms Palace llorse Car that ever came into the state of Massachusetts. I have never used any other since. During my business carcer I have shipped over 22,000 horses; the last 5,000 1 have shipped in your Arms Palace Horse Cars. The horses are ready for sale when they arrive here, and I must say I would not dispense with the use of them if it cost three times as much as it does.

$$
\text { Very respt'y yours, } \quad \text { T. S. SLOAN. }
$$


II. A. Yager, Secy Arms P'alace Ilorse Car Co., Chicago, IIl.

Boston, Mass., Jan. 22, 1889.

Dear Sir.- We have used the Arms Palace Horse Cars ever since they first came in use. We have seen several other patent cars for horses, but have never seen any. that we think equal the Arms Cars. We think a car of horses shipped in an Arms Car with a good man in charge, is worth $\$ 300$ more than a load shipped in a common vtock car. The expense is but little more, as what is saved from feed bills on the road will nearly pay for the use of the Arms Car. We have some large horses that we could not get to market without the use of a l'alace car. In the spring of 1888 many green horses died in hoston of typhoid pneumonia. We lost but very few compared with other dealers, and we think it was because we shipped in your cars, for this disease was caused by exposure in the common stock cars.

Yours respectfully,

E. HAM \& CO.

TILsonburc, Canada, Jan'y 22d, ISSg.

11. A. Yager, Sec'y Arms Paluce Horse Car Co., Checago, Ill.

Dear Sir:- We have been using your car for over three years, and we are greatly pleased with it. We ship quite largely to Manitoba, and our horses come out of your cars at end of route looking as weil as when they went in, after a trip of eight to ten lays. We loaded two of them here on the roth inst. for the Northwest. Could not think of shipping horses in ordinary cars after using the Arms Car.

Yours truly.

SCOTT d MULLER.

11. A. Yagere, Sec'y trms Palace Horse Car Co., Chicugo, IIl.

LA POKIE, Ind., Jan. 21, IS89.

Dear Sir:- We have been using the Arms I'alace Horse Car ever since they have lreen in use in shipping our horses from this place to loston, and have always had yood luck: we never having unloaded but once, and then only for an experiment, and (n) all occasions my horses came out of car looking and feeling as well as when first loaded. We have seen all the late improved horse cars and know of none so handy for feeding and taking care of horses when on the road as the Arms Car, and if stock is looked after and properly cared for, no one will have any trouble in getting their horses through in grood shape, and we take plesure in recommending this car to all

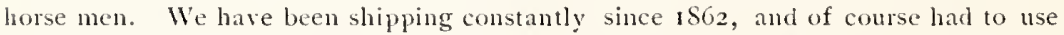
lhe old slat car up to the time the Arms Car came out, and we don't feel like going hack to the old style car again, as we can save much time, and time is money, and the quicker we can get our horses to market is what should interest all shippers.

$$
\text { Yours respectfully, J. P. DUNSMORE \& SON. }
$$


L.EN.l, IHI., Jall. 22, ISSg.

W. A. Viger, Secy trms Palute Itorse Car Co., Chicago, Ill.

Dear Sir:- I receivet your letler alt right this morning, and in answer will sily that you can say most anything in favor of the Arms Palace Car, and I will sanction it, for I think is the best car in use for shipping horses. We use no other.

I. UNDERWOOD \& CO.

Wrat Troy. N. V., Jan. 30, 1859

W. A. Jirser, Ser'y trms Palace Horse Car Co., Chicago, Ill.

Dear Sir:-In shipping horses from Ohio to this point I have patronized the Arms Palace IJorse Car ever since they were put in use, and I have found them tw meet every requirement of the business. For convenience and safety in the transpor tation of stock over a long distance without the necessity of unloading, they are cer tainiy far ahead of any car now in use for that purpose, and I have atways found m! tock in good condition upon arrival at destination.

I'HLIP WAMMES

Boston. Mass, Jan. 29, 1889

W. A. Yager, Se'ty Arms Palace Llorse Car Co., Chicago, Ill.

Dear Sir:--We have used your Palace Car for four or five years, and think it the hest car there is made for shipping horses. Do not see how we could get along without it, as the stock is so much fresher looking than by being shipped any other way.

Yours truly,

WELCII HALI.

NEW York, Jan. 25th, I $\$ 89$.

W. A. Yager, Secretury trms Pnlace Llorse Car Co., Chicago, Ill.

Dear Sir:-1 write to congratulate you on the success of your Palace Horse cars. I have been using them ever since you introduced them on the road, and I must say my horses come through from the west in as good shape as when they were loaded, and are fit to be shown as soon as they arrive. I have been shipping horsen from the West to sell on this market for the past thirty-five years, and I must say. since I began using your cars I do not know what it is to have a sick horse after shipping, as in former years. I also ship a good many imported draft stallions from this city to the West. Iave had them on the road for points in California and Or. gon for twenty-three days in your cars, and they were unloaded at destination feeling as fresh as when we shipped them.

United States Bonded and Sale Stables, Respectfully, 598-6oo Greenwich St., N. Y. City.

ROBERT STODDART. 
MT. Jor, L’a., Jan, 2 Ist, ISSg.

W. A. Yager, Sec'y Arms Pulace Horse Car Co., Chicago, IIl.

Dear Sir:-Regarding the Arms Cars, J desire to say that I have used your cars for my shipments from Peabory, Kansas, through to Lancaster, Pa., and that I am more than pleased with them, and the bencfits klerived from their use more than repay me for the extra charge made for service of cars, my stock when unloadcel aftcr a run of I 500 miles, being ready for market and not requiring any rest. I can recommend their usc to all shippers and would advise all who have nevcr used them to give them a trial, and can assure them that after having once used the Arms Car they will never go back to the old way of shipping. I shall start west in a few days and shall want you to supply me with three cars in Kansas for my next shipment.

$$
\text { Vours Very truly, J. II. ERB. }
$$

II. A. Yager, Secy Arms Palace Horse Car Co., Chicago, III.

PITTSFIELD, Ill., Jan. 26th, ISSg.

Dear Sir:- Wc take pleasure in syying that we have used the Arms Palace IIorse Car for a period covering about four years, and pronounce it the very best car for the purpose of shipping horses in use to day. We are fully satisfied that it is money in our pursc every time we use this car, anct cheerfully recommend it to all shippers of horses. Very truly yours, IBINS \& DOW.

II. A. Yager, Sec'y Arms Palace Horse Car Co., Chicago, Iil.

New Уork, Jan. 24, I8S9.

Dear Sir:- We have used your cars for more than five years, and we find them very satisfactory, and the best of any that we have used, for long as well as short shipments. We also think that they camnot be recommended too highly, as we have had extra good luck since we havc used them.

Yours Respt., I. H. WHITSON \& SON, Asents.

EAsT SAGINAW, Jan. 2I, ISSg.

IV. A. Yager, Sec'y Arms Palace Horse Cirr Co., Chicago, IIl.

Dear Sir:-Having used your cars for shipping horses the last three years for my shipments from points in Canada to this city, and the good success which has attended all my shipments in your cars, never having met with a loss or sustained an injury to a single animal, compels me to say that I consicter the Arms I'alace Horse Car the most practical car now in operation, and I cheerfully recommend the same to all shippers of horses.

Jours iruly,

HARRY BATES. 


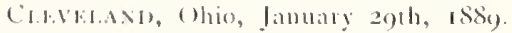

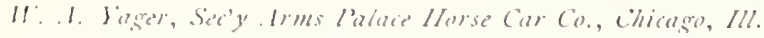

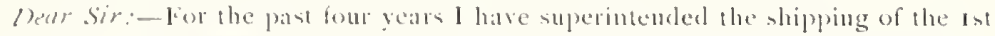
cleveland lioop's horses in your lalace Cars, to and from Chieago, Columbus and other cities, and consider them a steat comfort, hoth for the horses and the shipper. Ilave loadeal eighteen horsen in fifeen mimutes, and have never taken a horse from the car with even a scratch on him. I certanly recommend your cars as superior wo any I have eser uned for comfort, safety, ventilation, feeding facilities, in fact, every comvenience-would be at a great loss without them.

Vours very truly, II. BRULANG.

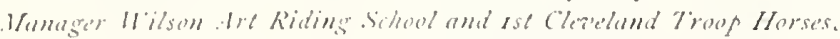

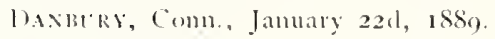

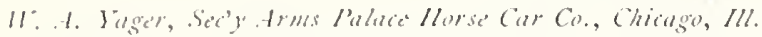

Dear Sir:-l have becu huying and shipping wescem horses east for about 20 years. I used the common entele and stoct car until I heard of the Arms I'alace Horse Car, about five years ago. I tried one and have used no other since, and never will. I can not aftord to as a mater of business, let the cost be what it will. Book me for the Arms Car every time when l have a lot of horses w ship, particularly a long distance. The difference is, in one case you lave a lot of horses jammed and banged all up, and sick on your hands; with the Amm Car, at your journey's end, your lorses are all in grood shape, ready to hitch and drive, use or sell. No other than the trms Cur for me. Very truly yours, IINIEY BR.MDIES.

RoxDorl, N. Y., Jan. 22, 1889.

II. 1. Yase'l, Se'y drms Palace Ilorse Cir Co., Chirago, III.

Dear Sim:-We have been shipping horses for over thirty (30) years, and we fund the Arms lalace llorse Car the most economical and convenient for carying horses, feed ant water, that we know of, and we would recommend them to all who are in the horse business. We remain,

Vours respectfully,

II. FORST \& SION.

liorl Coldixs, Colorado. January 23d, $18 S 9$.

II. 1. Yager, Secretary . Hom Paluce llorse Car Co., Chicago, IIl.

Dear Sir:-It affords me pleasure to say that your Palace Cars have given me the greatest satisfaction. I have long since recognized their superiority over other cars of the same class, consequently I have used them exclusively during the past two years. The manner of ventilation and eontrolling of drafts is simply perfeet.

lours very truly,

JESSE HARRIS. 
DE KALB, IHI., January 24, I 889 .

II. t. Hager, Esq., Secrelary Arms Pnlaie Horse Car Co., Chicago, Ill.

Dear Sir.-Replying to your favor of recent date, will say that we have used your ears quite extensively during the past three or four years, and have alway found them very satisfactory. The plan upon which they are constructed admits of easy and rapid loading and unloading of stock, as well as proper care and feeding while in transit. We have used other live stock cars, but can say truthfully that we have never seen anything that pleases us as much as the Arms.

Very truly yours, W. L. El.I,OOD.

II. Arms \& (o.. Tolede. Ohin.

Napoleon, Ohio, March 16, 1885.

. Wessis, :-Enclosed find Tew York draft for one hundred dollars, in payment for use of Your Palace Horse Cars from New York to Blackfoot, Idaho. Permit me (o) say that I am more than pleased with your car. We used it on a journey of about three thousand miles, and cluring the coldest weather last winter. Several times the mercury was helow $3^{\circ}$ yet we had no trouble. It would have been impossible tw have made the shipment in the ordinary car and saved my horses. The qualities of your car can le put to no more severe test than I gave them. I unloaded my horses direct from the steamer into the car and transported them from New York to the west side of the Rocky Mountains, during the severest weather of the winter withont loss, accident, trouble, or even annoyance. Alay all your patrons have similar expericnce, and share with me my high opinion of the car. Itost truly,

J. N. HIGH, of High \& Stout.

Normai, III., Jan. 21, I $88_{9}$.

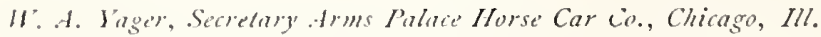

Dear Sir:- We have leen shipping horses more or less for over thirty years. harung used many different patterns of cars. We have used your car and no other since I 884 . We consider it snperior to any car now in use. We use it exclusively wo ship our stock to the fairs. We can ship stock in better condition than in any other car we crer nsed. We made the first shipment in your regular line cars, they being the first of your ear ever offered the public. This shipment was from here to the New Orleans Exposition. and we hope we shall never be compelled to use any other ar.

Yours truly,

DILLON BROS. 
()skilousi, towa, Jin. 21, 188a.

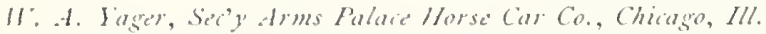

lear sir:- As importers of lirench draft horses, we desire to express our satis faction, not only in the use of your cars, but also at the prompt and gentlemanly way we have been treated in every respect by your company. We have used for a num Ixer of years past, the Arms l'alace Car, and we find then convenient and comforta ble. Cau load rapidly, are well rentilated and suitable for shipping in any season.

$$
\text { Vours very truly, SPRIN( \& WII.AKL. }
$$

Importers and Biereders of French Draft Ilorsc's.

Winkkk1), Lake Co., 1). T., Jan. 26, I8S9.

troms Palace Horse Car Co., Chicaso, Ill.

Gentlemen:- I take pleasure in reeommending to any who may have horsen in course of transportation, the Arms l'alaee llorse Car. We have used it exelusively, and have yet to report the loss or clamage of any anmal. We have had horses on the road, without unloading, for thitteen or fourteen days, from Boston here, and horves came out of the car looking fine.

lours truly,

EDIIKI) L. BRAIBURV, P'r's'.

NEW lokk, leb'y 12 th, 1889.

II. .1. Yager, Sec'y Alms Palace Horse Car Co., Chicago. Ill.

Dear Sir:- We have been using your lalaee Car now for about two years, and ave promised you that we would let you know, after a fair trial, what we though of them, we now beg to give you our experience. We first used the common ear, believing it unwise to pay an additional eharge, but found our horses were delivered in bad condition. We then tried your ear, and one or two others, and cleeided in favor of your ear. Our experienee has eonvineed us that we aeted wisely in doing so, hecause, in addition to the general health of the horse on his arrival being good, his weight has been sustained through the long trip from Cheyenne here. As a matter of fact, roo horses weighed at Clieyenne and in New Vork, showed a loss of less than inn pounds apiece. We therefore feel it due to you to say that we think your car is the best in use, and that any concern, in our judgement, shipping horses, would save money by using it, to say nothing of the eonvenience of loading and unloading.

Very respectfully yours,

POST PERCHERON HORSE ASSOCIATION.

LEANDER WATHRBRY, See'y. 
L. ExixgTu, Ky.. Jan, $25^{\text {th, } 1 S S 9 .}$

II: 4. Jasere, Sec'y drms Palace llorse Car Co., Chicago, Ill.

Dear Sir:- We have used the Arms I'alace Horse Car for several years, and cousider then the best cars for shippung stock in that we have ever used, and cheer. fully recommend them to the public. Very resp'y, TRACEY \& WILSON.

P'ITTABRe, Pa, Jan. 22, iss9.

If'. A. Jager, Sec'y trms Pralace Hlorse Ciar Co., Chicago, IIl.

Dear Sir:-During last season I used your cars especially designed and con. structed for the transportation of horses, and found them convenient and comfort. able, easy riding and well equipped. Very truly yours,

SAM'L S. BROWN.

Ci.evFl...X, O., Jan. 21, $18 S_{9}$.

II: A. Sager, Sec'y Arms Prrlace Thorse Car Co., Chicagro, IIl.

Denr Sir:-Wishing to express my good fcelings toward the Arms Palace Hore ("ar, for the benefit I lave derived from their use by such shipments as the one from Valley Falls, Kansas, to Randall, Ohio, with twelve brood mares and six foals by their side, they all arriving in good condition, which was more than I expected for 6 long a trip, and with so young stock. Also my trip to Columbus, Georgia. Having started from Randall in a good frcight car, Mr. Fiuller was obliged to transfer to one of your cars after reaching Cincinnatti. Also my second shipment to Brantford, Ont.. which gives me the worth of my money in the condition of the stock in transit.

Yourstruly, C. F. EMERY:

Bostox. Jan. $25^{\text {th, }}$ is 8 .

II. A. Hager, Sec'y Arms Palace Horse Car Co., Chrougo, Ill.

Dear Sir:-I have used the Arms Palace Horse Car for a number of years, and consider it not only a good thing, hut a necessity in shipping herses in safety.
I remain,
lours truly,
JOHN R. GRAIIAI.

Trov, Ohio, Jan. 21, 1889. IV. A. Jager, Sec"y trms Palace IJorse Car Co., Chicagro, Ill.

Dear Sir:-It is with pleasure that we testify to the merits of the Arms Palace Horse Car. We have found them all one could wisls, and for the safe transportation of valuable horses we regard the Arms Car indispensablc. Wishing you success with them we are; Yours truly,

DVE \& STILLWELI. 


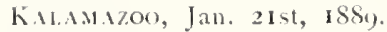

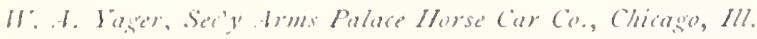

Dear Sir:- We have used the Armo l'alace llorse Car from date of its introduc tion, and can cheerfully recommend it to shippers of horses and cattle as a substantial, convenient, casy riding and well ventilated car, and also recommend the company for their prompt and efficient service to their patrons.

Verye truly gours,

¿. A. BROWNE \& CO.

Butralo, Erie Co., X. Y., Jan. $21 \mathrm{st}, \mathbf{8 8 8}$.

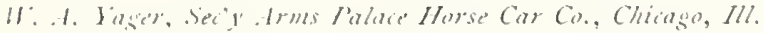

Dear Sir:- We have used your car between our stock farm at East Aurora, X. Y., and Cheney, Kansan, (a distance of 1200 miles) and they have always giren 1 the very best of satisfation. Vou can refer to ns all any time, and we shall be pleased to recomment them in the strongest manner.

lours.

HEXKY $\therefore$ JEWETT \&

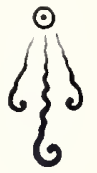




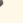




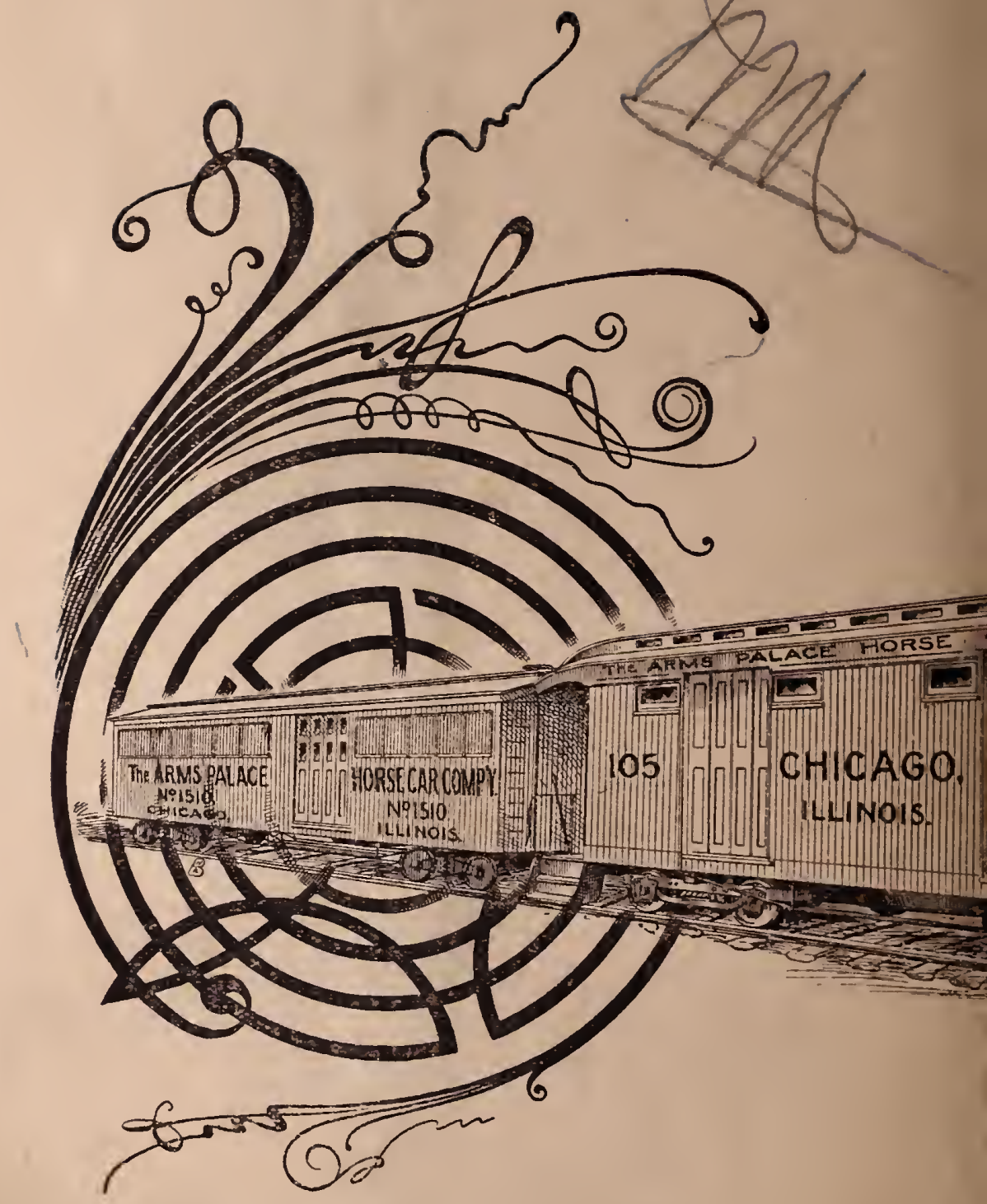

